\title{
INHIBITION BY COLCHICINE OF IMMUNOREACTIVE VASOACTIVE INTESTINAL POLYPEPTIDE RELEASE FROM ANTERIOR PITUITARY CELLS IN CULTURE
}

\author{
Fernando Sanchez ${ }^{1}$, Jose I. Lara ${ }^{2}$, Lucinda Cacicedo ${ }^{2}$, Franco Sanchez-Franco ${ }^{2}$, Jose Carretero ${ }^{1}$ \\ and RICARDO VAZQUEZ ${ }^{1}$ \\ ${ }^{1}$ Department of Human Anatomy and Histology, Faculty of Medicine, University of Salamanca, 37007, Salamanca, and ${ }^{2}$ Endocri- \\ nology Service, Ramón y Cajal Hospital, 28084, Madrid, Spain
}

\begin{abstract}
We investigated the effect of colchicine on the release of vasoactive intestinal polypeptide (VIP) from adenohypophyseal cells in culture, measuring VIP by radioimmunoassay. Additionally, prolactin (PRL) and growth hormone $(\mathrm{GH})$ release was studied. Exposure of cultured pituitary cells to colchicine for 3 or $6 \mathrm{~h}$ caused a significant decrease in the release of immunoreactive VIP (IR-VIP) into the media, concomitantly with an increase in IR-VIP in cells. Long-term exposure to the drug (12 and $24 \mathrm{~h}$ ) leads to a dramatic decrease in IR-VIP in cells. These findings are similar to those obtained for PRL and GH. Though the exact nature of VIP-producing adenohypophyseal cell(s) is not known, the results suggest that microtubules play an important role in the mechanism responsible for VIP release from adenohypophyseal cells in culture.
\end{abstract}

Vasoactive intestinal polypeptide (VIP), originally isolated from porcine duodenum (30), has been shown to be present in the anterior pituitary by means of various experimental methods $(2,3,10$, 19, 31, 36).

Although, it seemed initially that VIP and prolactin (PRL) are produced in the same cell (17), a different population of VIP-producing cells in the anterior pituitary, functioning as regulator of lactotrophs, have recently been described $(29,36)$.

It is well-known that colchicine, a mitosis-inhibiting drug, interferes with the secretory activity of various endocrine and exocrine cells $(7,8,12,15$, 26-28, 37). This drug depolymerizes microtubules to tubulin and suppresses the transport of granules, resulting in an accumulation of secretory products. Thus colchicine is commonly used to increase the reaction intensity in various immunocytochemical studies $(6,9,16,20-25,32-34,38)$.

In order to know whether microtubules are involved in the secretion of different adenohypophyseal hormones, the effect of colchicine on anterior pituitary cells in monolayer culture has pre- viously been investigated $(1,11)$. However, the effect of this drug on the release of adenohypophyseal VIP has not yet been investigated.

We attempted in the present study to elucidate the effect of colchicine on the VIP release from anterior pituitary cells in culture. For comparison, we have also examined the well-known release of PRL and growth hormone (GH).

\section{MATERIALS AND METHODS}

\section{Cell Culture}

Male Wistar rats (180-200 g) were sacrificed by decapitation. The anterior pituitary glands were removed, collected in Earle's balanced salt solution (EBSS) and rinsed three times with the same solution. The pituitaries were then placed in a $15-\mathrm{ml}$ tube containing $0.15 \% \mathrm{MgCl}_{2}, 0.1 \%$ papain, $0.1 \%$ deoxyribonuclease, and $0.1 \%$ neutral protease and dispersed. The pituitary fragments were incubated in a water-jacketed incubator for $1 \mathrm{~h}$ at $37^{\circ} \mathrm{C}$. The rate of dispersion was increased by gently drawing the fragments in and out of a Pasteur pipette every 
30 min. After $1 \mathrm{~h}$ the cell suspension was centrifuged at 3,000 rpm for $5 \mathrm{~min}$. The supernatant was discarded, and the sedimented cells were resuspended in an appropriate volume of Dulbecco's modified Eagle's medium (DMEM) containing 3\% fetal serum, $100 \mathrm{U} / \mathrm{ml}$ penicilin, $100 \mathrm{U} / \mathrm{ml}$ streptomycin, and $0.1 \mathrm{mU}$ glutamine was freshly added $(4,35)$.

Cells were placed in tissue culture dishes $(30 \times$ $15 \mathrm{~mm}$ ) at a concentration of $5 \times 10^{5}$ cells $/ 1.5 \mathrm{ml} /$ plate, and placed in an incubator at $37^{\circ} \mathrm{C}$ under an atmosphere of $5 \% \quad \mathrm{CO}_{2} / 95 \%$ air. Media were changed on the third day of incubation. Experiments were performed after 4 days of incubation.

\section{Experiments with Colchicine}

At the beginning of each experiment, the media were discarded, and the cells were rinsed with EBSS; and fresh DMEM without serum $(1.5 \mathrm{ml})$ and without or with colchicine $(3 \mu \mathrm{g} / 1.5 \mathrm{ml}$ medium) was then added. After $3,6,12$ or $24 \mathrm{~h}$, the culture dishes were chilled on ice, and the media were collected. Cells were washed with ice-cold $0.01 \mathrm{M}$ phosphate/0.15 M NaCl (pH 7.4) buffer (PBS), resuspended in $1 \mathrm{ml}$ of $\mathrm{PBS}$ and sonicated for $15 \mathrm{sec}$. Media and cell extracts were centrifuged at $3,000 \mathrm{rpm}$ for $30 \mathrm{~min}$. Supernatants were kept frozen for later measurement of immunoreactive VIP, GH and PRL. Protein concentrations were measured according to Lowry et al. (14), and were found to be similar in each of the dishes.

\section{Immunoassays}

PRL and GH were assayed, with modifications, according to the protocol provided by the National Pituitary Hormone Distribution Program (NIAMMD, Bethesda, MD), by a double antibody radioimmunoassay (PRL or VIP), or by protein A radioimmunoassay (GH). VIP was assayed as previously described (14).

\section{Statistical Analysis}

This was made with the Student $t$-test and with the ANOVA test. Values at $P<0.05$ were considered statistically significant.

\section{RESULTS}

\section{Effects of Colchicine on VIP Release}

Incubation of pituitary cells with colchicine signif-- 1a: MEDIA
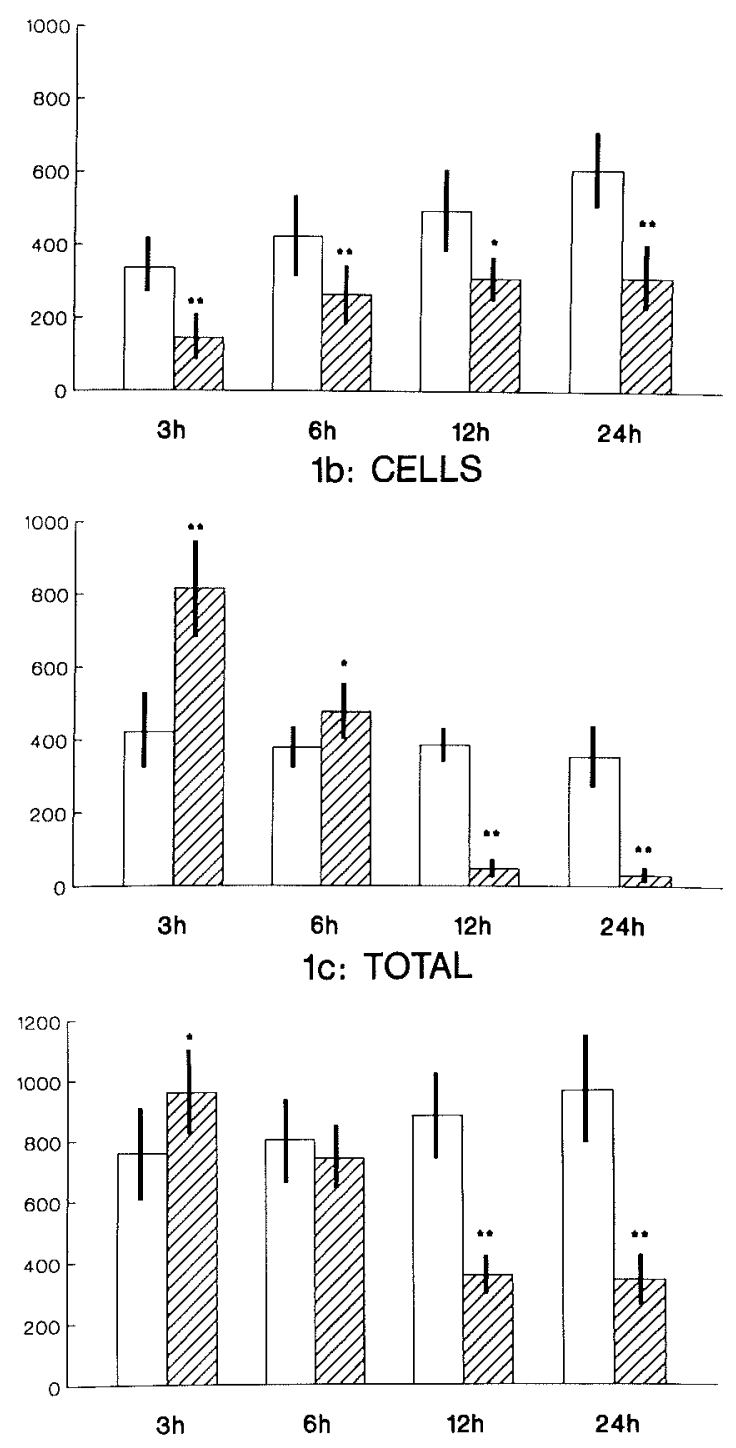

Fig. 1 IR-VIP in media (a), cells (b) and its total amount (c) in the control and colchicine-treated culture dishes. Values are expressed in picograms/plate \pm SD. ${ }^{*} P<0.05$, and ${ }^{* *} P<0.01$ vs control. Open column, control (10 dishes); striped column, colchicine-treated (10 dishes)

cantly decreased IR-VIP release into the media at all times studied $(3,6,12$ and $24 \mathrm{~h}$ ), whereas the amount of immunoreactive VIP (IR-VIP) in cells was increased markedly after $3 \mathrm{~h}$, nearly equivalent with the control at $6 \mathrm{~h}$, and decreased dramatically at 12 and $24 \mathrm{~h}$ (Fig. 1, a and b). In the control, basal IR-VIP release was increased during incubation, being maximum at $24 \mathrm{~h}$, whereas IR-VIP in cells remained almost unchanged (Fig. 1, a and b). The 
2a: MEDIA
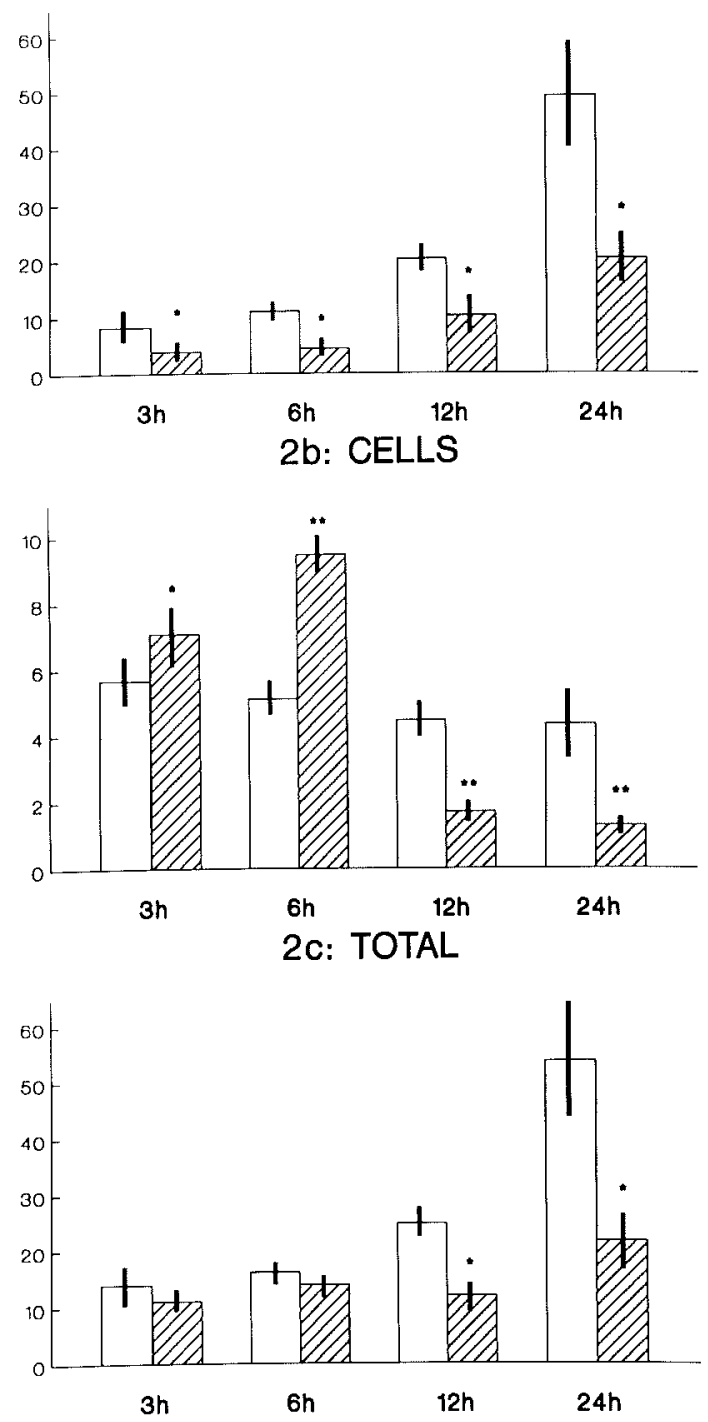

Fig. 2 IR-PRL in media (a), cells (b) and its total amount (c) in the control and colchicine-treated culture dishes. Values are expressed in micrograms/plate \pm SD. ${ }^{*} P<0.05$, and $* P<0.01$ vs control. Open column, control (10 dishes); striped column, colchicine-treated (10 dishes)

total IR-VIP showed no clear differences between the control and colchicine-treated-dishes at 3 and $6 \mathrm{~h}$ (Fig. 1c). However, a long-term exposure to colchicine (12 and $24 \mathrm{~h}$ ) caused a significant decrease in the total amount of IR-VIP $(P<0.01)$ compared with the control (Fig. 1c).

The total IR-VIP in the control dishes was slightly increased throughout the incubation time, indicating the viability of VIP-producing cells 3a: MEDIA
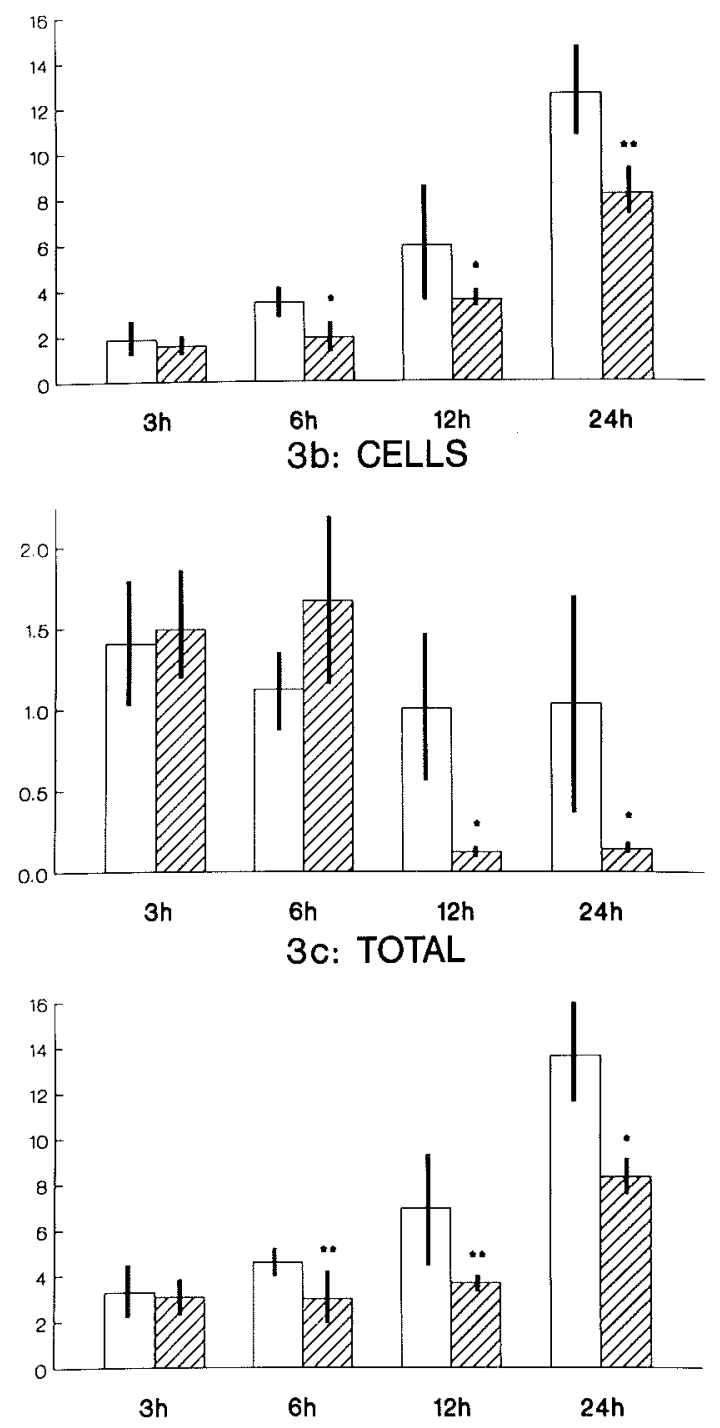

Fig. 3 IR-GH in media (a), cells (b) and its total amount (c) in the control and colchicine-treated culture dishes. Values are expressed in micrograms/plate \pm SD. ${ }^{*} P<0.05$, and ${ }^{* *} P<0.01$ vs control. Open column, control (10 dishes); striped column, colchicine-treated (10 dishes)

under the present culture conditions (Fig. 1c).

Effects of Colchicine on PRL or GH Release Effects of colchicine on the release of PRL or GH were, in general, similar to those observed for VIP. Treatment with colchicine caused a clear decrease in IR-PRL or IR-GH in media $(P<0.01)$ (Figs. 2a and $3 a)$. Their intracellular content was increased 
at 3 and $6 \mathrm{~h}$ (Figs. 2b and 3b). Long-term incubation (12 or $24 \mathrm{~h}$ ) resulted in a considerable decrease in their intracellular content, amounting to $50 \%$ or higher.

The total amount of IR-PRL or IR-GH did not statistically differ $(P>0.05)$ at 3 and $6 \mathrm{~h}$ between the control and colchicine-treated cells (Figs. 2c and $3 \mathrm{c}$ ). A long-term exposure to colchicine resulted in a marked decrease in both hormones when compared with the control $(P<0.01)$ (Figs. $2 \mathrm{c}$ and $3 c)$.

\section{DISCUSSION}

It is well known that VIP is synthesized in adenohypophyseal cells $(2,3,19,31,36)$. Our present results indicate that adenohypophyseal cells in culture can produce and release VIP. It is also demonstrated that colchicine inhibits the release of not only PRL and GH, but also the release of VIP from cultured cells.

Colchicine rapidly inhibits the VIP release $(3 \mathrm{~h})$, with an increase in the intracellular peptide content. Similar effects can be observed at $6 \mathrm{~h}$. However, in a long-term exposure to colchicine the intracellular IR-VIP content was dramatically decreased, suggesting either an increase in VIP degradation or a diminished VIP-synthesis. Colchicine exerts similar effects on GH or PRL.

With regard to PRL, our present results agreed with findings in a previous paper (1). The paper described a rapid inhibition by colchicine of PRL release $(4 \mathrm{~h})$ in anterior pituitary cells in monolayer culture; this inhibition was accompanied by an increase in the intracellular content even after the 24-h treatment. A drastic decrease in the amount of intracellular PRL occurred after this period. We observed a marked decrease in intracellular decrease PRL at $12 \mathrm{~h}$, but this minor discrepancy may be explained in terms of the different dose of colchicine used.

Labrie et al. (11) showed a time-dependent inhibitory effect of vincristine on the GH release and on the basal and stimulated release of PRL in cultures of hemipituitaries ( $1 \mathrm{~h}$ after incubation). Following a short-term incubation $(4 \mathrm{~h})$ with colchicine or vincristine, disappearance of microtubules accompanied by an accumulation of secretory granules were seen, whereas a long-term exposure resulted in a marked decrease in the number of granules and the appearance phagocytic features ( 1 , 11). These morphological findings were found in all pituitary cell types.

Although the nature of the pituitary VIP-producing cells has not been identified yet, similar changes in microtubules are expected to occur in these cells. This implies that microtubules are involved in the secretion processes in the VIP-producing cells. The exact knowledge of VIP-producing cells will clarify whether VIP exerts a paracrine (5) rather than an autocrine effect (18).

The authors wish to express their gratitude to E.L. Shorten for kindly revising the English expressions in the manuscript. This work was supported by a DGICYT PB86/0213 project, Spanish Ministry of Education and Science.

Received 19 November 1990; and accepted 9 January 1991

\section{REFERENCES}

1. Antakly T., Pelletier G., Zeytinoglu F. and Labrie F. (1979) Effects of colchicine on the morphology and prolactin secretion of rat anterior pituitary cells in monolayer culture. Amer: J. Anat. 156. 353-372

2. Arnaout M. A., Garthwaite T. L., Martinson D. R. and HAGEN T. C. (1986) Vasoactive intestinal polypeptide is synthesized in anterior pituitary tissue. Endocrinology 119, 2052-2057

3. Besson J., Rotsztejn W. H. and Bataille D. (1982) Involvement of VIP in neuroendocrine functions. In Vasoactive Intestinal Peptide (ed. SAID S. I.) Raven Press, New York, pp. 253-262

4. CACICEDo L. and Franco F. S. (1986) Direct action of opioid peptides and naloxone on gonadotropin secretion by cultured rat anterior pituitary cells. Life Sci. 38, 617-625

5. Denef C., Baes M. and Schramme C. (1986) Paracrine interactions in the anterior pituitary: Role in the regulation of prolactin and growth hormone secretion. In Frontiers in Neuroendocrinology (ed. Ganong W. F. and Martini L.) Raven Press, New York, pp. 115-148

6. Flament-Durand J. and Dustin P. (1972) Studies on the transport of secretory granules in the magnocellular hypothalamic neurons. I. Action of colchicine on axonal flow and neurotubules in the paraventricular nuclei. Z. Zellforsch $130,440-454$

7. Gillespie E., Levine R. J. and Malawista S. E. (1968) Histamine release from rat peritoneal mast cells: Inhibition by colchicine and potentiation by deuterium oxyde. J. Pharmacol. Exp. Ther: 164, 158-165

8. Herman G., Busson S., Gorbunoff M. J., Mauduit P., Timasheff S. N. and Rossignol B. (1989) Colchicine analogues that bind reversibly to tubuline define microtubular requirements for newly synthesized protein secretion in rat lacrimal gland. Proc. Natl. Acad. Sci. USA 86, 4515-4519

9. Hindelang-Gertner C., Stoeckel M.-E., Porte A. and STUTINSKY F. (1976) Colchicine effects on neurosecretory neurons and other hypothalamic hypophysial cells, with special reference to changes in the cytoplasmic membranes. Cell Tissue Res. 170, 17-41

10. Köves K., Gottschall P. E., Görcs T., Scammell J. G. and ARIMURA A. (1990) Presence of immunoreactive 
vasoactive intestinal polypeptide in anterior pituitary of normal male and long term estrogen-treated female rats: A light microscopic immunohistochemical study. Endocrinology 126, 1756-1763

11. Labrie F., Gauthier M., Pelletier G., Borgeat P., Lemay A. and Gouge J.-J. (1973) Role of microtubules in basal and stimulated release of growth hormone and prolactin in rat adenohypophysis in vitro. Endocrinology 93, 903-914

12. LaCY P. E., Howell S. L., Young D. A. and Fink C. J. (1968) New hypothesis of insulin secretion. Nature 219, $1117-1179$

13. Lorenzo M. J., Sánchez-Franco F., De Los Frailes M. T., Reichlin S., Férnandez G. and Cacicedo L. (1989) Synthesis and secretion of vasoactive intestinal peptide by rat fetal cerebral cortical and hypothalamic cells in culture. Endocrinology 125, 1983-1990

14. Lowry O. H., Rosebrough N. J., Farr A. L. and Randall R. J. (1951) Protein measurement with the folin phenol reagent. J. Biol. Chem. 193, 265-275

15. Malaisse W. J., Leclercq-Meyer V., Van Obberghen E., Somers G., Devis G., Ravazzola M., Malaisse-Lagae F. and ORCI L. (1975) The role of the microtubular-microfilamentous system in insulin and glucagon release by the endocrine pancreas. In Microtubules and Microtubule Inhibitors (ed. Borgers M. and De BraBANDER M.) NorthHolland, Amsterdam, pp. 143-153

16. MezeY E and Kiss J. Z. (1985) Vasoactive intestinal peptide-containing neurons in the paraventricular nucleus may participate in regulating prolactin secretion. Proc. Natl. Acad. Sci. USA 82, 245-247

17. Morel G., Besson J., Rosselin G. and Dubois P. M. (1982) Ultrastructural evidence for endogenous vasoactive intestinal peptide-like immunoreactivity in the pituitary gland. Neuroendocrinology 34, 85-89

18. NaGy G., Mulchahey J. J. and Neill J. D. (1988) Autocrine control of prolactin secretion by vasoactive intestinal peptide. Endocrinology 122, 364-366

19. Nicosia S., Spada A. and Giannattasio G. (1982) Effects of vasoactive intestinal polypeptide on the pituitary gland. In Vasoactive Intestinal Peptide (ed. SAID S. I.) Raven Press, New York, pp. 263-275

20. Norström A. and Hansson H.-A. (1973) Effects of colchicine on release of neurosecretory material from the posterior pituitary gland of the rat. Z. Zellforsch. 142, 443-464

21. Norström A., Hansson H.-A. and Sjöstrand J. (1971) Effects of colchicine on axonal transport and ultrastructure of the hypothalamo-neurohypophyscal system of the rat. $Z$. Zellforsh 113, 271-293

22. Norström A. and SJöstrand J. (1971) Axonal transport of proteins in the hypothalamo-neurohypophysial system of the rat. J. Neurochem. 18, 29-39

23. Norström A and SJöstrand J. (1971) Transport and turnover of neurohypophysial proteins of the rat. $J$. Neurochem. 18, 2007-2016

24. Parish D. C., Rodriguez E. M., Birkett S. D. and PickerING B. T. (1981) Effects of small doses of colchicine on the components of the hypothalamo-neurohypophysial system of the rat. Cell Tissue Res. 220, 809-827

25. Peña P., Rodriguez E. M., Dellmann H.-D. and Schoebitz K. (1988) Effects of colchicine on the hypothalamo-neurohypophysial system of chronically salt-loaded rats. Nellroendocrinology 47, 217-224

26. Poisner A. M. and Bernstein J. (1971) A possible role for microtubules in catecholamine release from adrenal medulla: effect of colchicine, vinca alkaloids and deuterium oxide. J. Pharmacol. Exp. Ther: 177, 102-108

27. Redman C. M. (1983) Role of cytoskeleton in liver: $I n$ vivo effect of colchicine on hepatic protein secretion. Meth. Enzymol. 98, 169-175

28. Redman C. M., Banerjee D., Howell K. and Palade G. E. (1975) Colchicine inhibition of plasma protein release from rat hepatocytes. J. Cell Biol. 66, 42-59

29. REICHLIN S. (1988) Neuroendocrine significance of vasoactive intestinal polypeptide. In Vasoactive Intestinal Peptide and Related Peptides (ed. Said S. I. and MutT V.) Ann. New York Acad. Sci., pp. 431-449

30. SaID S. I. and MutT V. (1970) Polypeptide with broad biological activity: Isolation from small intestine. Science $169,1217-1218$

31. Samson W. K., Said S. I. and McCann S. M. (1979) Radioimmunologic localization of vasoactive intestinal polypeptide in hypothalamic and extrahypothalamic sites in the rat brain. Neurosci. Lett. 12, 265-269

32. Sanchez F., Carretero J., Riesco J. M., Juanes J. A. and VAZQUEZ R. (1988) Effect of a high dose of colchicine administered intracerebroventricularly to the corticotropic hypothalamic-hypophyseal axis of the rat. An immunocytochemical study. Anales. Anatomia. 34, 91-99

33. Sanchez F., Carretero J., Rubio M., Blanco E., Riesco J. M. and VAZQUEZ R. (1988) Topographical distribution of vasopressin-producing neurons in the paraventricular nucleus of the rat hypothalamus following adrenalectomy and treatment with colchicine. Neuroendocrinol. Lett. 10, 165174

34. Sanchez F., Carretero J., Sanchez-Franco F., Riesco J. M., Blanco E., Juanes J. A. and VAzQuez R. (1990) Morphometric changes of specific located vasopressin-reacting parvicellular neurons in the paraventricular nucleus of the rat after adrenalectomy. Neuropeptides 17, 127-134

35. SÁNCHEZ-Franco F. and CaCiCEDo L. (1986) Inhibitory effect of $\beta$-endorphin on gonadotropin-releasing hormone and thyrotropin-releasing hormone releasing activity in cultured rat anterior pituitary cells. Hormone Res. 24, 55-61

36. Segerson T. P., Lam K. S. L., Cacicedo L., Minamitani N., FinK J. S., Lechan R. M. and Reichlin S. (1989) Thyroid hormone regulates vasoactive intestinal peptide (VIP) mRNA levels in the rat anterior pituitary gland. Endocrinology. 125, 2221-2223

37. Williams J. A. and WolfF J. (1970) Possible role of microtubules in thyroid secretion. Proc. Natl. Acad. Sci. USA 67, 1901-1908

38. WILSON L. (1970) Properties of colchicine binding protein from chick embryo brain. Interactions with vinca alkaloids and podophyllotoxin. Biochemistry 9, 4999-5007 